\title{
Possible Evidence for Endogenous Production of a Novel Galanin-like Peptide
}

\author{
Zhi-Li Wang, Rohit N. Kulkarni, Ren-Ming Wang, David M. Smith, Mohammad A. Ghatei, Peter G.H. Byfield, William M. Bennet, \\ and Stephen R. Bloom \\ Francis Fraser Labs, Division of Endocrinology and Metabolic Medicine and Haemostasis Research Unit, Hammersmith Hospital, \\ Royal Postgraduate Medical School, London W12 0NN, United Kingdom
}

\begin{abstract}
Galanin mRNA and peptide are not detectable in normal islets. We studied the effect of galanin antagonists on insulin secretion in the rat $\beta$ cell line, RIN5AH, and in perifused rat islets. In RIN cell membranes galanin and its antagonists showed high affinity for ${ }^{125} \mathrm{I}$-galanin binding sites $\left[K_{d}\right.$ : (galanin) $0.03 \pm 0.01 ; K_{i}$ for galanin antagonists: (C7) $0.12 \pm$ 0.02, (M35) 0.21 \pm 0.04 , and (M40) $0.22 \pm 0.03 \mathrm{nM}$, mean \pm SEM, $n=4]$. Galanin (1 $\mu \mathrm{M})$ inhibited glucose-induced insulin release in islets (control $21.2 \pm 1.5$ vs. galanin $4.5 \pm 0.2$ fmol/islet per min, $P<0.001, n=6$ ) and RIN5AH cells (control $0.26 \pm 0.01$ vs. galanin $0.15 \pm 0.02$ pmol $/ 10^{6}$ cells per h, $P<0.001, n=9$ ). In RIN5AH cells, all antagonists blocked the inhibitory effects of galanin and stimulated insulin release in the absence of galanin. C7 and M40 (1 $\mu \mathrm{M})$ alone significantly stimulated glucose-induced insulin secretion. Purified porcine galanin antibody (GAb) enhanced glucose-induced insulin release from islets (control 100土 $16.3 \%$ vs. GAb $806.1 \pm 10.4 \%, P<0.001, n=6$ ), and RIN5AH cells (control $100 \pm 9.6 \%$ vs. GAb $149 \pm 6.8 \%, P<$ $0.01, n=6$ ). Western blotting of dexamethasone-treated islet extracts using GAb showed a specific band of similar molecular weight to porcine galanin not detected using a rat specific galanin antibody. One possible explanation for these results is the presence of an endogenous galanin-like peptide. (J. Clin. Invest. 1997. 100:189-196.) Key words: galanin $\bullet$ islet $\bullet$ antagonist $\bullet$ antibody $\bullet$ RIN cells
\end{abstract}

\section{Introduction}

Rat galanin is an amidated 29-amino acid peptide encoded by a single gene $(1,2)$, and is present within adrenergic and peptidergic nerve fibers innervating pancreatic islets $(3,4)$. Stimulation of the mixed autonomic and sympathetic nerves releases galanin from pancreatic nerves and inhibits insulin secretion

Z.-L. Wang and R.N. Kulkarni contributed equally to this study.

This work was presented in part at the American Diabetes Association meeting, 1995, Atlanta, GA.

Address correspondence to Dr. Stephen R. Bloom, Professor of Endocrinology, Department of Metabolic Medicine, Hammersmith Hospital, Du Cane Road, London W12 0NN, United Kingdom. Phone: 44-181-740-3044; FAX: 44-181-740-3142; E-mail: sbloom@ rpms.ac.uk

Received for publication 29 August 1996 and accepted in revised form 10 April 1997.

J. Clin. Invest.

(C) The American Society for Clinical Investigation, Inc.

0021-9738/97/07/0189/08 \$2.00

Volume 100, Number 1, July 1997, 189-196
$(5,6)$. Studies in the rat, mouse (3), and dog (7) provide evidence that the release of galanin in the pancreas is under similar control to norepinephrine $(8,9)$. Immunofluorescent staining for galanin in the dog pancreas has shown galanin-like immunoreactivity in nerves innervating the islets (10). Galanin-like immunoreactivity has not been found in intrapancreatic ganglia (11), pointing to an extrapancreatic location for galanin-containing cell bodies (12). These findings are supported by the inability to detect galanin mRNA in normal islet tissue $(13,14)$ and the lack of galanin in isolated islets from normal rats.

The pancreatic content of galanin is 2-10-fold decreased in hyperinsulinemic diabetic-obese $o b / o b$ and male $d b / d b$ mice $(15,16)$ compared to lean mice. In mice stressed by swimming, insulin secretion in response to glucose is blunted by $50 \%$ compared to nonswimming control mice. This decrease of insulin secretion during exercise is abolished in animals pretreated with galanin immunoneutralizing sera (16). This suggests the possibility that galanin could have a role in limiting insulin secretion during exercise or stress $(17,18)$. The antisera-induced reduction of insulin secretion in these studies suggests either the reversal of a neuroendocrine tone in the islet or an effect on the intraislet paracrine system. In our pilot studies, treatment of insulinoma cells with a galanin antagonist and a galanin antibody, respectively, showed an increase in insulin secretion (19), thus suggesting a possible direct effect on the islet $\beta$ cell. We therefore undertook this study to investigate further the effects of novel high-affinity galanin antagonists and a purified galanin antibody on glucose-induced insulin secretion in rat insulinoma cell line, subclone $5 \mathrm{AH}(\mathrm{RIN} 5 \mathrm{AH})^{1}$ cells and isolated rat islets.

\section{Methods}

Chemical sources. Galanin (rat and porcine), galanin(1-13)-spantideamide (C7), and galanin(1-13)-pro-ala-leu-ala-leu-ala-amide (M40) were synthesized by Fmoc chemistry and HPLC-purified. The fidelity of synthesis was confirmed by fast atom bombardment mass spectrometry. Galanin(1-13)-bradykinin(2-9)amide (M35) was obtained from the School of Biochemistry, University of Birmingham, United Kingdom. Substance P, spantide, bradykinin, and all other chemicals of Analar grade were obtained from Sigma Chemical Co. (Poole, Dorset, United Kingdom).

1. Abbreviations used in this paper: $\mathrm{B}_{\max }$, maximal binding capacity; C7, Gly-Trp-Thr-Leu-Asn-Ser-Ala-Gly-Tyr-Leu-Leu-Gly-Pro-D-ArgPro-Lys-Pro-Gln-Gln-D-Trp-Phe-D-Trp-Leu-Leu-amide; GAb, galanin primary antibody; M35, Gly-Trp-Thr-Leu-Asn-Ser-Ala-Gly-Tyr-LeuLeu-Gly-Pro-Pro-Pro-Gly-Phe-Ser-Pro-Phe-Arg-amide; M40, Gly-TrpThr-Leu-Asn-Ser-Ala-Gly-Tyr-Leu-Leu-Gly-Pro-Pro-Ala-Leu-AlaLeu-Ala-amide; RIN5AH, rat insulinoma cell line, subclone 5AH; RPMI, Rosewell Park Memorial Institute; spantide, D-Arg-Pro-LysPro-Gln-Gln-D-Trp-Phe-D-Trp-Leu-Leu. 
Cell culture. RIN5AH cells were cultured in RPMI 1640 medium (1.2 mM glucose) with $10 \% \mathrm{vol} / \mathrm{vol}$ fetal calf serum (GIBCO BRL, Paisley, Scotland) in an atmosphere of $95 \% \mathrm{O}_{2}, 5 \% \mathrm{CO}_{2}$, and $100 \%$ humidity at $37^{\circ} \mathrm{C}(20,21)$. Culture media were supplemented with antibiotics and all experiments were carried out between passages 1824. RIN5AH cells were plated to a density of $1-2 \times 10^{5}$ cells/well in a total volume of $1 \mathrm{ml}$ as described earlier (22). Briefly, cells were grown for $48 \mathrm{~h}$ to allow attachment, washed twice with serum-free RPMI medium and preincubated in glucose-free RPMI 1640 medium for $2 \mathrm{~h}$. This was followed by incubation of the cells for $3 \mathrm{~h}$ in RPMI 1640 medium and either galanin, C7, M35, M40, or purified galanin antibody. After the incubation period, medium was collected, centrifuged, and the supernatant was stored at $-20^{\circ} \mathrm{C}$ for subsequent insulin radioimmunoassay (RIA). Cell viability was $>92 \pm 2.1 \%(n=29)$ as assessed by trypan blue exclusion and cell counts ranged from 0.4 to $0.8 \times 10^{6}$ cells $/$ well.

Membrane preparation and receptor binding studies. Membranes were prepared from RIN5AH cells (23). Briefly, cells were grown to confluence in $175 \mathrm{~cm}^{2}$ flasks and homogenized in ice-cold $50 \mathrm{mM}$ Tris/ $\mathrm{HCl}$ buffer, $\mathrm{pH} 7.4$, containing $0.25 \mathrm{M}$ sucrose, $10 \mathrm{mg} /$ liter soya bean trypsin inhibitor, $0.5 \mathrm{mg} /$ liter pepstatin, $0.25 \mathrm{mg} /$ liter leupeptin and antipain, $0.1 \mathrm{~g} /$ liter benzamidine, and $28 \mathrm{mg} /$ liter aprotinin (Trasylol $^{\circledR}$; Bayer Pharmaceutical, West Haven, CT). The homogenates were centrifuged at $1,500 \mathrm{~g}$ for $20 \mathrm{~min}$ and then supernatants were recentrifuged at $100,000 \mathrm{~g}$ for $1 \mathrm{~h}$ at $4^{\circ} \mathrm{C}$. The pellets were resuspended to a final protein concentration of $5-10 \mathrm{~g} /$ liter and stored at $-80^{\circ} \mathrm{C}$. The protein content was measured by the Biuret method (24). Receptor binding studies were carried out as previously described using iodogen-labeled porcine ${ }^{125}$ I-galanin (25). Briefly, membranes were incubated in $20 \mathrm{mM}$ Hepes buffer ( $\mathrm{pH} 7.4$ ) containing $5 \mathrm{mM} \mathrm{MgCl}$, $0.1 \%$ (wt/vol) bacitracin, $5.6 \mu \mathrm{g} / \mathrm{ml}$ aprotinin, $1 \mathrm{mM}$ EDTA, and $1 \%$ (wt/vol) BSA, in the presence of $0.1 \mathrm{nM}^{125}$ I-galanin (specific activity $9 \mathrm{~Bq} / \mathrm{fmol}$ ), in a final volume of $0.5 \mathrm{ml}$. Nonspecific binding was determined in the presence of $200 \mathrm{nM}$ galanin. Specific binding was calculated as total binding minus nonspecific binding.

Islet isolation and perifusion. Male Wistar rats weighing $300-350 \mathrm{~g}$ (Banting and Kingman, Hull, United Kingdom) were maintained under controlled conditions of light ( $12 \mathrm{~h}$ light/dark cycle) with an ambient temperature between 20 and $25^{\circ} \mathrm{C}$ and food and water available ad libitum. All animals were killed by $\mathrm{CO}_{2}$ overdose. Islets were isolated by the intraductal collagenase method $(26,27)$ and $50-100$ islets were used in each chamber. The islets were placed in a volume of 2 $\mathrm{ml}$ on a $5.0-\mu \mathrm{m}$ filter (SV; Millipore Corp., Bedford, MA) which was supported on a $20-\mu \mathrm{m}$ nylon mesh in the bottom of a 5-ml syringe which formed the perifusion chamber. The dead space including the volume in the tubing is $\sim 3.2 \mathrm{ml}$. A peristaltic pump (502 S; WatsonMarlow, Falmouth, Cornwall, United Kingdom) was used to control the media flow through the chamber. Islets were perifused with a 50: $50 \mathrm{vol} / \mathrm{vol}$ mixture of Krebs-Ringer buffer and CMRL 1066 culture medium which was supplemented with BSA $(0.4 \%)$, bacitracin 40 $\mathrm{mg} / \mathrm{liter}$, aprotinin $7 \mathrm{mg} / \mathrm{liter}$, and ascorbic acid $80 \mathrm{mg} / \mathrm{liter}$. The medium, $\mathrm{pH} 7.4$, was equilibrated with $5 \% \mathrm{CO}_{2}$ and $95 \% \mathrm{O}_{2}$ before and during the experiment. The perifusion chambers were immersed in a water bath at $37^{\circ} \mathrm{C}$ and islets were perifused with buffer at $0.4 \mathrm{ml} / \mathrm{min}$. Fractions of $1.6 \mathrm{ml}$ were collected every 4 min using a programmed automatic fraction collector (Superfrac; Pharmacia Biotech AB, Uppsala, Sweden). Islets were equilibrated for a 40-min period with buffer containing $2.8 \mathrm{mM}$ glucose $(-40-0 \mathrm{~min})$ before the start of sample collection and for the first $40 \mathrm{~min}$ of collection ( $0-40 \mathrm{~min})$. Thereafter, from time 40-160 min the glucose concentration was increased to $8 \mathrm{mM}$ to stimulate insulin secretion. This was followed by a second 40-min period of perifusion with buffer containing $2.8 \mathrm{mM}$ glucose (160-200 $\mathrm{min}$ ). To assess islet viability at the end of the experiments, insulin secretion was stimulated with $16 \mathrm{mM}$ glucose for $20 \mathrm{~min}$ (200$220 \mathrm{~min}$ ). Peptides were dissolved in the perifusion buffer immediately before their use and were added to the system from time 80-120 min during stimulation of insulin secretion with $8 \mathrm{mM}$ glucose. Each perifusion study was undertaken with a paired control and was repli- cated six times. The perifusion effluent was stored at $-20^{\circ} \mathrm{C}$ before RIA for insulin.

Islet primary culture. For experiments on the effect of galanin antibody, groups of freshly isolated islets (100 islets $/ \mathrm{ml})$ were incubated with the control and galanin antibodies in primary culture in sterile 6-well plates (Falcon; Marathon Laboratory Supplies, London, United Kingdom) for a period of $16 \mathrm{~h}$. The medium was RPMI 1640 supplemented with L-glutamine $(0.3 \mathrm{mg} / \mathrm{ml}), 10 \%$ fetal calf serum, $100 \mu \mathrm{g} / \mathrm{ml}$ streptomycin sulphate, and $100 \mathrm{U} / \mathrm{ml}$ benzyl penicillin, maintained at $37^{\circ} \mathrm{C}$ in an atmosphere of $5 \% \mathrm{CO}_{2}$ and $95 \% \mathrm{O}_{2}$ at $100 \%$ humidity. After the incubation, the medium in the wells was removed and centrifuged at $1,000 \mathrm{~g}$ for $5 \mathrm{~min}$ and the supernatant was stored at $-20^{\circ} \mathrm{C}$ for RIA.

Immune purification of galanin antibody. Galanin polyclonal antiserum prepared in rabbits immunized with unconjugated porcine galanin was further purified using the Immunopure $\mathrm{IgG}$ purification kit (Pierce Chemical Co., Rockford, IL). The final eluate was dissolved in culture media and used at dilutions of 1:100, 1:30, and 1:10, $\mathrm{vol} / \mathrm{vol}$, in islet and cell culture experiments. Controls included $(a)$ no addition of antiserum, $(b)$ nonimmune serum pooled from four different sources, and $(c)$ antisera raised against bombesin and pneumadin (28). All sera were subjected to the same purification procedure.

Radioimmunoassay. Insulin secretion in perifusate and culture medium was measured by a specific RIA using porcine insulin standard. Antibodies to insulin were raised by injection of glutaraldehyde conjugated porcine insulin to BSA in guinea pigs (Glu5), and was used at a final dilution of 1:800,000. This antibody cross-reacts identically with human, porcine, and rat insulin at all concentrations used. Tracer was prepared by the iodogen method (29) and had a specific activity of $82 \mathrm{~Bq} / \mathrm{fmol}$. Rat galanin RIA was used for measuring galanin immunoreactivity. Galanin antiserum raised in rabbits to unconjugated synthetic rat galanin, was used at a final dilution of 1:256,000. The tracer prepared by the iodogen method (29) had a specific activity of $48 \mathrm{~Bq} / \mathrm{fmol}$. Both assays had a detection limit of $2 \mathrm{fmol} /$ tube at 95\% confidence. Rat islets, RIN5AH cells, and rat ileum (control) were extracted in acid ethanol overnight at $4^{\circ} \mathrm{C}$ for galanin RIA

Western blotting. Tissue samples were prepared by isolating 600 islets each from normal and dexamethasone $(4 \mathrm{mg} / \mathrm{kg}$ body weight, subcutaneously for $10 \mathrm{~d})(30)$ treated rats. RIN5AH cells $\left(2 \times 10^{7}\right)$ and islets were extracted in acid ethanol overnight at $4^{\circ} \mathrm{C}$. Samples

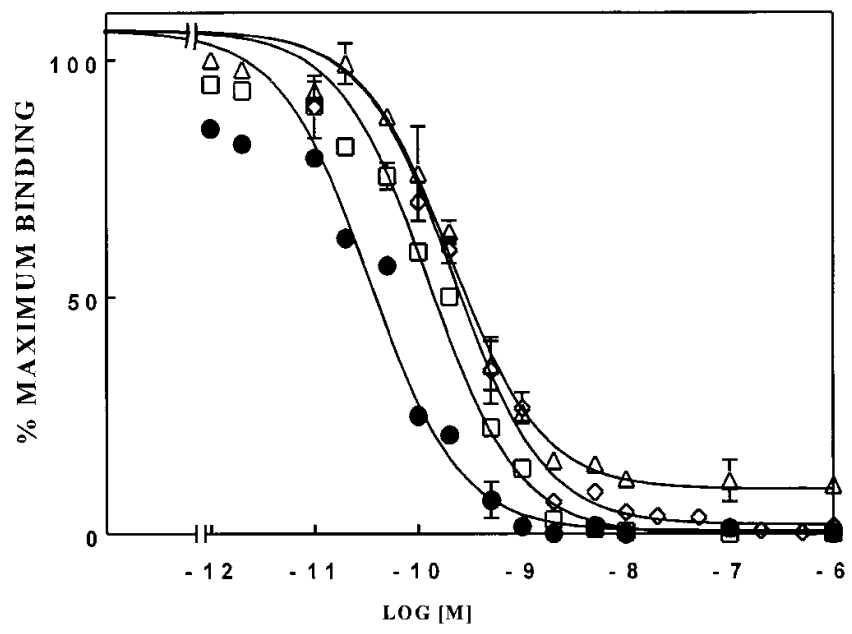

Figure 1. Competition for ${ }^{125}$ I-galanin by galanin $(\bullet), C 7(\square)$, M35 $(\triangle)$, and M40 $(\diamond)$ in membranes prepared from RIN5AH cells. The calculated $K_{\mathrm{d}}$ value for galanin was $0.03 \pm 0.01 \mathrm{nM}$ and $K_{\mathrm{i}}$ values for the antagonists were $0.12 \pm 0.02(\mathrm{C} 7), 0.21 \pm 0.04$ (M35), and $0.22 \pm 0.03(\mathrm{M} 40) \mathrm{nM}, n=4$. Experiments each performed in triplicate. 
were dried in a Savant vacuum drier (Savant Instruments Inc., Farmingdale, NY) and resuspended in $\times 2$ sample buffer (31) heated to $95^{\circ} \mathrm{C}$ for $2 \mathrm{~min}$ and loaded at a protein concentration of $120 \mu \mathrm{g} / 35 \mu \mathrm{l}$ into the sample well. Tissue extracts were electrophoretically separated on a $16.5 \%$ Tris-tricine gel (Mini-PROTEAN II; Bio-Rad, Hercules, CA) and run at $100 \mathrm{~V}$ for $2 \mathrm{~h}$ under reducing ( $2 \% \beta$-mercaptoethanol) conditions. Porcine and rat galanin were run as controls. Transfer blotting was carried out essentially as described earlier (31). The membrane was blocked overnight in 5\% milk-PBS, incubated for $3 \mathrm{~h}$ in a 1:500 dilution of porcine or rat purified galanin primary antibody (GAb) and washed three times in $0.1 \%$ Tween-PBS. The membrane was exposed to $10^{6} \mathrm{cpm}\left[{ }^{125} \mathrm{I}\right]$ donkey anti-rabbit secondary antibody (1:2,000, Amersham International plc, Amersham, United Kingdom) for $1 \mathrm{~h}$ at $22^{\circ} \mathrm{C}$, washed five times in $0.1 \%$ Tween-PBS, dried, and autoradiographs obtained over $72 \mathrm{~h}$ at $-80^{\circ} \mathrm{C}$ on Kodak XAR5 film (Eastman Kodak Co., Rochester, NY).

Statistical analysis. Statistical analysis of the static incubation experiments was carried out by ANOVA with post hoc Tukey tests and for the perifusion data by the Student's paired $t$ tests. The perifusion results presented are time course, means, and SE for each 40-min phase of study. The effect of the experimental peptides was compared to the results obtained from paired control chambers from a single harvest pool run synchronously. Figures in parentheses indicate the number of times the experiment was carried out. The receptor maximal binding capacity $\left(\mathrm{B}_{\max }\right), K_{\mathrm{d}}$, and $K_{\mathrm{i}}$ values were calculated by nonlinear regression using the ReceptorFit Competition-Heterologous Ligands program (Lundon Software, Inc., Cleveland, $\mathrm{OH}$ ).

$\mathbf{A}$
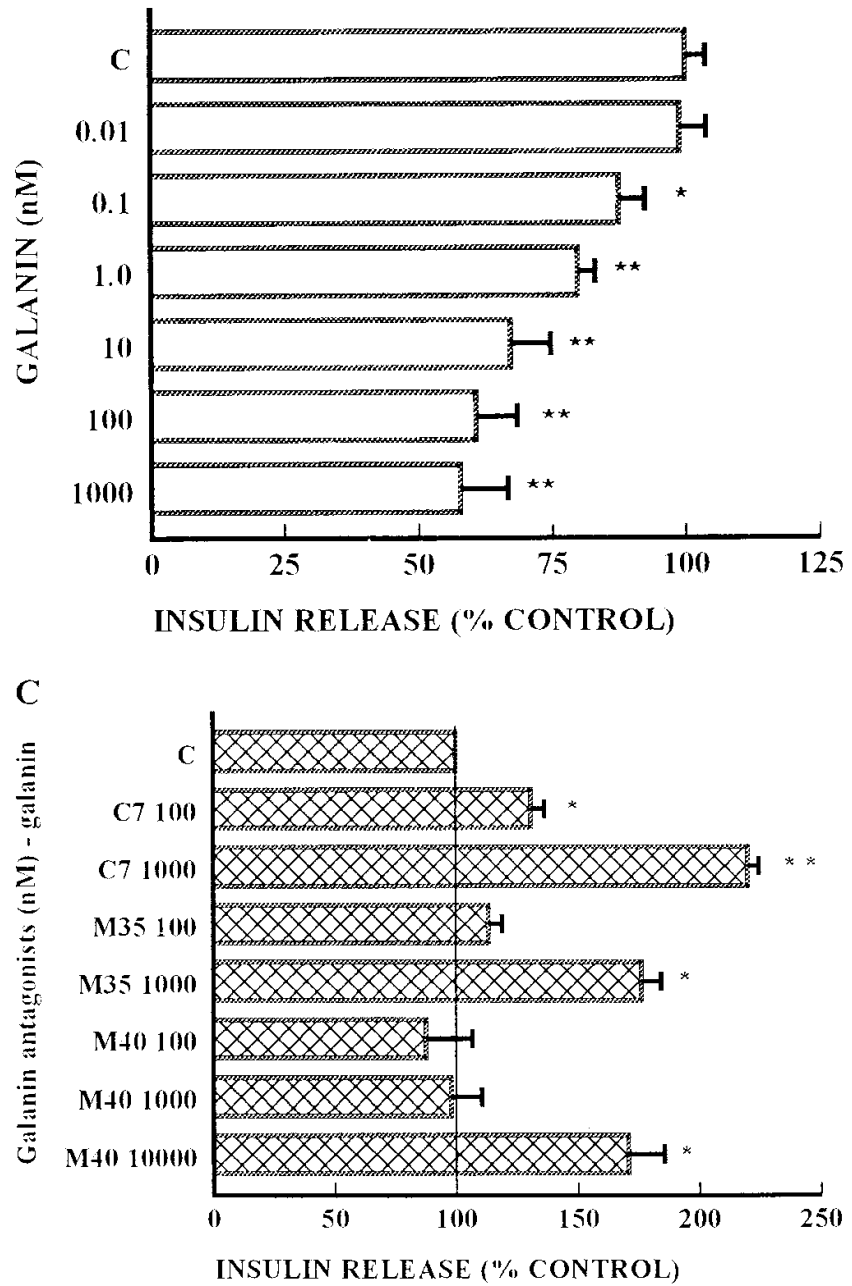

\section{Results}

\section{Receptor binding studies}

RIN5AH cells expressed galanin binding sites as previously shown for RINm5F cells (32). Galanin and its antagonists C7, M35, and M40 competed for binding of ${ }^{125}$ I-galanin (Fig. 1). $K_{\mathrm{d}}$ for galanin was $0.03 \pm 0.01 \mathrm{nM}$, and the $K_{\mathrm{i}}$ values for the galanin antagonists were $0.12 \pm 0.02$ (C7), $0.21 \pm 0.04$ (M35), and $0.22 \pm 0.03 \mathrm{nM}(\mathrm{M} 40)$, mean $\pm \mathrm{SEM}, n=4 . \mathrm{B}_{\max }$ was $102 \pm 19$ $\mathrm{fmol} / \mathrm{mg}$ protein, $n=7$.

\section{Effect of galanin and galanin antagonists on insulin release}

RIN CELLS

Effect of galanin. Fig. $2 \mathrm{~A}$ shows the dose response for galanin inhibition of insulin release. A significant reduction was observed for $0.1 \mathrm{nM}$ and greater concentrations, with a $43 \%$ reduction produced by $1 \mu \mathrm{M}$ galanin $(P<0.01$, control vs. gala$\operatorname{nin}, n=9)$.

Effects of C7, M35, and M40 in the presence of $10 \mathrm{nM}$ galanin. Fig. $2 B$ shows the effect of addition of the galanin antagonists C7, M35, and M40 at concentrations of 100 and 1,000 $\mathrm{nM}$ on insulin release from RIN5AH cells in the presence of 10 $\mathrm{nM}$ galanin. All three antagonists abolished the inhibitory effect of galanin. C7 $(100 \mathrm{nM})$ abolished the inhibitory effect of galanin $(10 \mathrm{nM})(P=\mathrm{NS}, n=12)$ and increased insulin release

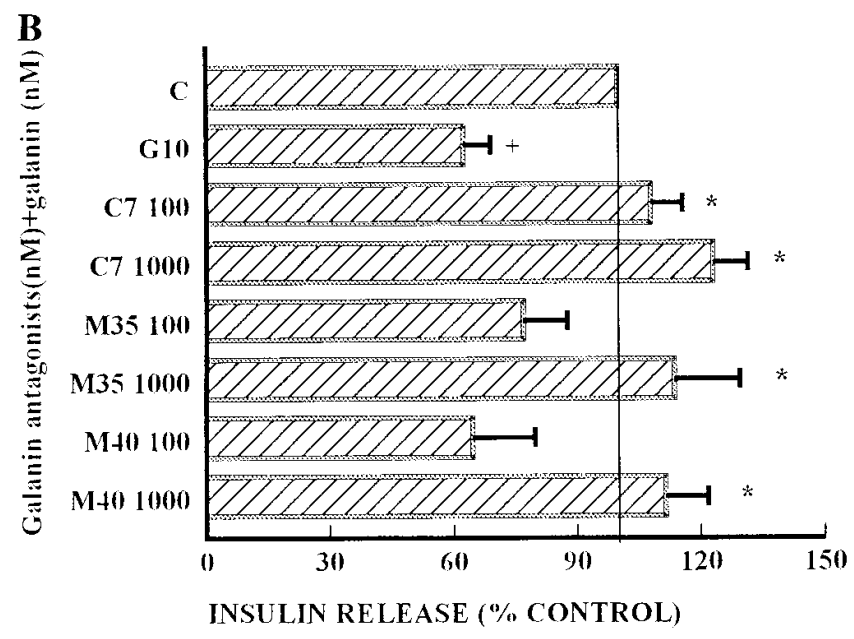

Figure 2. (A) Dose-response curve for the effect of galanin on insulin release from RIN5AH cells. $* P<0.05$ vs. control, $* * P<0.01$ vs. control $(n=9)$. The control insulin secretion was $0.26 \pm 0.01 \mathrm{pmol} / 10^{6}$ cells per h. (B) Effect of 100 and 1,000 $\mathrm{nM}$ each of C7, M35, and M40 on galanin-induced $(G, 10 \mathrm{nM})$ insulin release from RIN5AH cells incubated for 120 min. ${ }^{+} P<0.01 \mathrm{G}$ vs. control. ${ }^{*} P<0.01, \mathrm{G}$ vs. C7 100, C7 1000, M35 1000, and M40 $1000(n=8-12)$. The control insulin secretion for the experiments were: $\mathrm{C} 7,0.24 \pm 0.03$; M35, 0.22 \pm 0.03 ; and M40, $0.26 \pm 0.02 \mathrm{pmol} / 10^{6}$ cells per h. (C) Effect of incubation of C7, $\mathrm{M} 35$, and M40 separately in the absence of galanin on insulin release from RIN5AH cells. $* P<0.01$ vs. control; $* * P<0.001$ vs. control $(n=8-12)$. The control insulin secretion for the experiments were: $\mathrm{C} 7$, $0.2 \pm 0.02 ; \mathrm{M} 35,0.21 \pm 0.02 ; \mathrm{M} 40,0.24 \pm 0.02 \mathrm{pmol} / 10^{6}$ cells per h. In $A$, $B$, and $C$ the control is denoted as $\mathrm{C}$. 
above control levels at $1 \mu \mathrm{M}$. M35 at 1,000 nM prevented the galanin $(10 \mathrm{nM})$-induced reduction of insulin release $(P<$ 0.01 , galanin vs. M35+galanin, $n=8)$. M40 at $1,000 \mathrm{nM}$ also abolished the effect of galanin $(10 \mathrm{nM})(P<0.01$, galanin vs. M40+ galanin, $n=8$ ).

Effects of C7, M35, and M40 in the absence of galanin. All three antagonists increased insulin release from RIN5AH cells in the absence of galanin (Fig. $2 \mathrm{C}$ ). An increase in insulin release was observed with $\mathrm{C} 7$ alone at $100 \mathrm{nM}$, and at $1 \mu \mathrm{M}$ insulin secretion was increased by twofold $(P<0.001$, control vs. C7, $n=12$; Fig. $2 C$ ). M35 alone at $1 \mu \mathrm{M}$ significantly increased insulin release $(P<0.01$, control vs. M35, $n=8)$. However, a stimulatory effect of M40 was observed only at the higher concentration of $10 \mu \mathrm{M}(P<0.01$, control vs. M40, $n=8)$.

Effects of substance $P$, spantide, and bradykinin. No differences in insulin secretion from RIN5AH cells were observed when increasing concentrations of substance $\mathrm{P}$, spantide, or bradykinin were tested separately up to concentrations of $1 \mu \mathrm{M}$ (control $100 \pm 16.7 \%$ vs. spantide $116.7 \pm 13.0 \%$, vs. substance $P$ $100 \pm 13.6 \%$, vs. bradykinin $93.3 \pm 14.8 \%, P=\mathrm{NS}, n=4)$. The control insulin release was $0.28 \pm 0.03 \mathrm{pmol} / 10^{6}$ cells per $\mathrm{h}$.

\section{PERIFUSED ISLETS}

Effect of galanin. Baseline insulin release was $100 \pm 3.5 \%(n=$ 6) from islets in the control chambers in the presence of 2.8 $\mathrm{mM}$ glucose, during time $0-40 \mathrm{~min}$ (Fig. $3 A$ ). There was a 3.5fold rise to $348 \pm 10.1 \%(P<0.01$ vs. baseline, $n=6)$ when the glucose concentration was increased to $8 \mathrm{mM}$ during $40-80$ min. In the second 40-min period with $8 \mathrm{mM}$ glucose (80-120 $\mathrm{min}$ ), insulin release from control chambers increased to $731 \pm 7.1 \%(P<0.01$ vs. baseline, $n=6)$ and remained stable during the third period with $8 \mathrm{mM}$ glucose from 120 to 160 min. Insulin release decreased during the subsequent period with $2.8 \mathrm{mM}$ glucose from 160 to $200 \mathrm{~min}(75.9 \pm 4.5 \%, P=\mathrm{NS}$ vs. baseline, $n=6)$ and significantly rose again (579.3 $\pm 7.1 \%$, $P<0.01$ vs. baseline, $n=6$ ) with $16 \mathrm{mM}$ glucose during time 200-220 min. Insulin release from galanin-treated chambers matched those for control chambers before the addition of galanin. During the addition of $1 \mu \mathrm{M}$ galanin, from 80 to 120 min, insulin release was suppressed by $80 \%$ compared to control chambers $(P<0.001$, control vs. galanin, $n=6$, Fig. $3 A)$. There was a rapid increase in insulin release during the 40-min period after the removal of galanin stimulus (120-160 min), such that mean insulin release almost matched $(P=0.052)$ that from untreated control chambers. The insulin release then paralleled that for control chambers during the fall with 2.8 $\mathrm{mM}$ glucose from 160 to $200 \mathrm{~min}$ and the subsequent rise with $16 \mathrm{mM}$ glucose (200-220 min).

Effect of $\mathrm{C} 7$ and galanin. Before the addition of a mixture of $\mathrm{C} 7$ and galanin, the pattern of insulin release was not different from that seen for the control islets (Fig. $3 \mathrm{~B}$ ). Insulin release was $104.3 \pm 18.7 \%$ during the addition of $1 \mu \mathrm{M}$ galanin combined with $1 \mu \mathrm{M} \mathrm{C7}$ (80-120 min) which was not different from that for untreated islets $(P=\mathrm{NS}$, control vs. $\mathrm{C} 7+$ galanin, $n=6$, Fig. $3 B$ ). The inhibitory action of galanin was therefore abolished by $\mathrm{C} 7$, suggesting that $\mathrm{C} 7$ is a galanin antagonist at the $\beta$ cell.

Effect of $C 7$ alone. Before the addition of experimental peptide, the pattern of insulin release for C7-treated islets and islets in control chambers was similar (Fig. $3 B$ ). When $1 \mu \mathrm{M}$ C7 was added alone (80-120 min) insulin release was increased

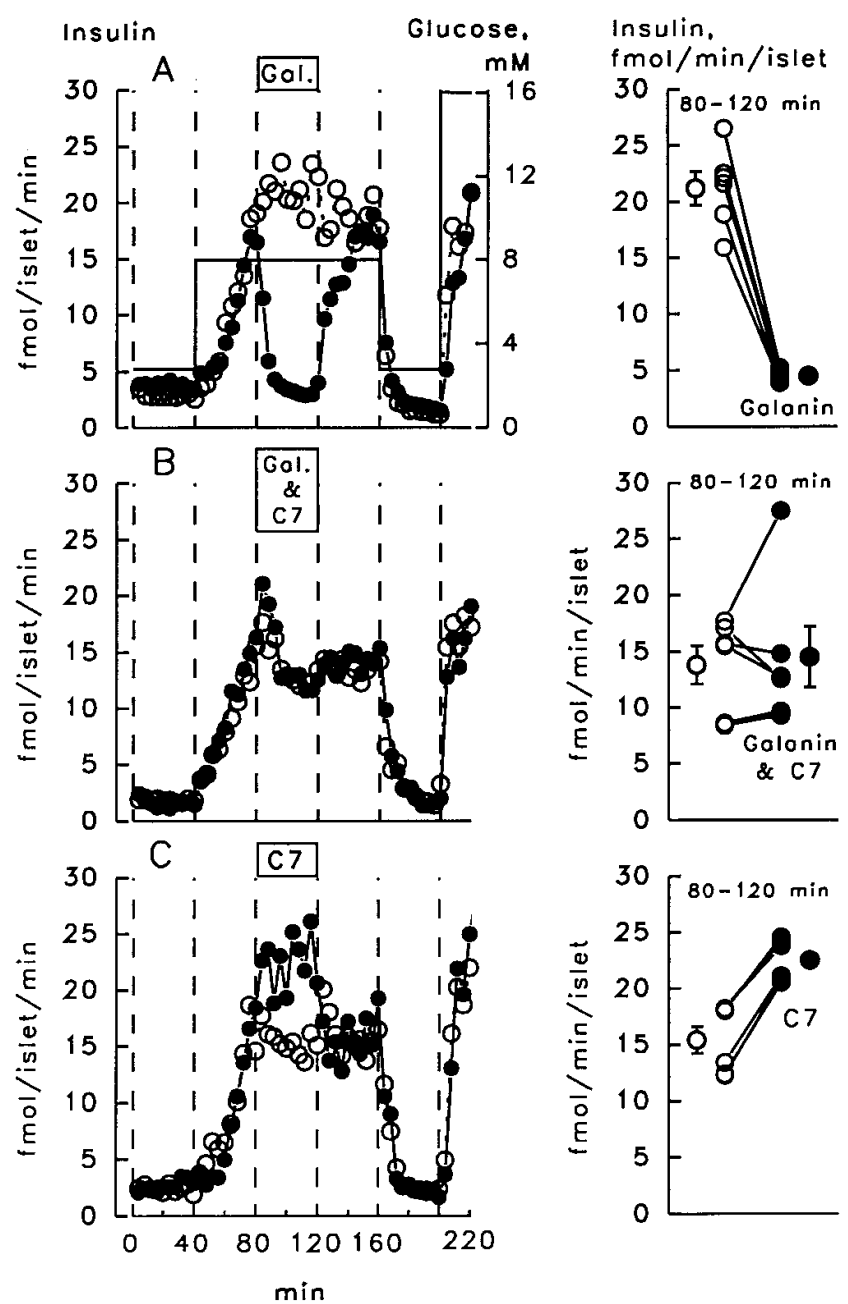

Figure 3. $(A)$ Insulin release from perifused rat islets was decreased $(P<0.001, n=6)$ during $80-120$ min when galanin was added $(\bullet)$ versus untreated controls $(O)$. The glucose concentration was $8 \mathrm{mM}$ during the treatment period. Left-hand panels show time course and the right-hand panels show individual paired mean \pm SE results for the period 80-120 min when peptide was added. (B) Insulin release was not different from islets treated with galanin $+\mathrm{C} 7(\bullet)$ versus no peptide $(\bigcirc)$, indicating that the effect of galanin was blocked by concomitant C7 $(n=6)$. ( $C)$ Insulin release was increased $(P<0.001$, $n=6)$ by $\mathrm{C} 7$ treatment $(\circlearrowleft)$ compared to control $(\bigcirc)$ values. The control insulin secretion rates were $(A) 2.9 \pm 0.1,(B) 2.2 \pm 0.1$, and $(C)$ $2.4 \pm 0.1 \mathrm{fmol} /$ islet per $\mathrm{min}$.

by $46 \%(P<0.001$, control vs. $C 7, n=6$, Fig. $3 C$ ). Insulin release from $\mathrm{C} 7$-treated chambers thereafter matched those for control chambers, during the 40-min period (120-160 min) after the addition of $\mathrm{C} 7$, and during the periods with $2.8 \mathrm{mM}$ glucose (160-200 $\mathrm{min}$ ) and $16 \mathrm{mM}$ glucose (200-220 min).

Effect of M40 and galanin. Incubation of M40 $(1 \mu \mathrm{M})$ in the presence of galanin $(1 \mu \mathrm{M})$ abolished the inhibitory effect of galanin and the insulin release was not different from that of the control chambers (control $5.9 \pm 0.8$ vs. galanin $+\mathrm{M} 40$ $5.5 \pm 0.9 \mathrm{fmol} /$ islet per $\mathrm{min}, P=\mathrm{NS}, n=6$ ).

Effect of M40 alone. Addition of $1 \mu \mathrm{M}$ M40 alone (80-120 min) increased insulin release by $29 \%$ compared with control chambers (control $5.9 \pm 0.8$ vs. M40 $7.6 \pm 0.5 \mathrm{fmol} /$ islet per min, $P<0.05, n=6)$. No differences in insulin release were ob- 
A

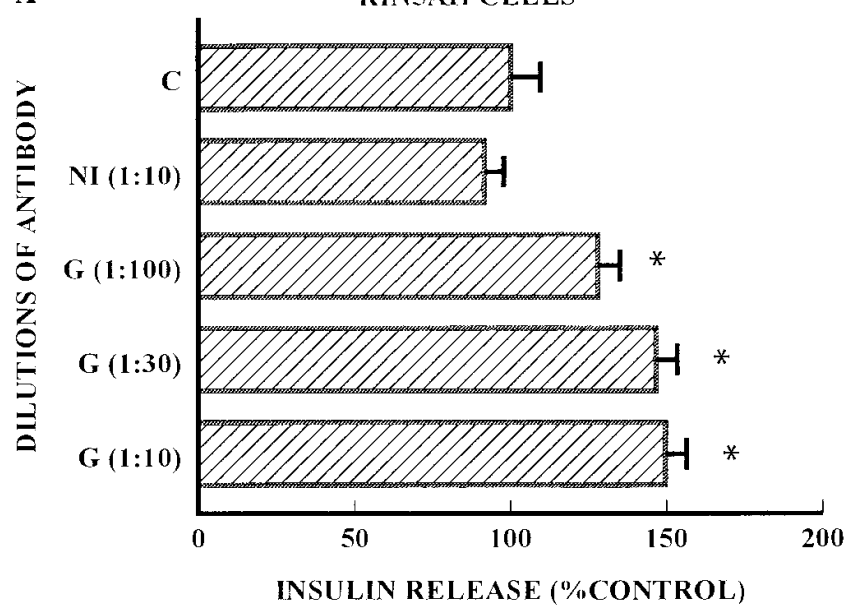

B

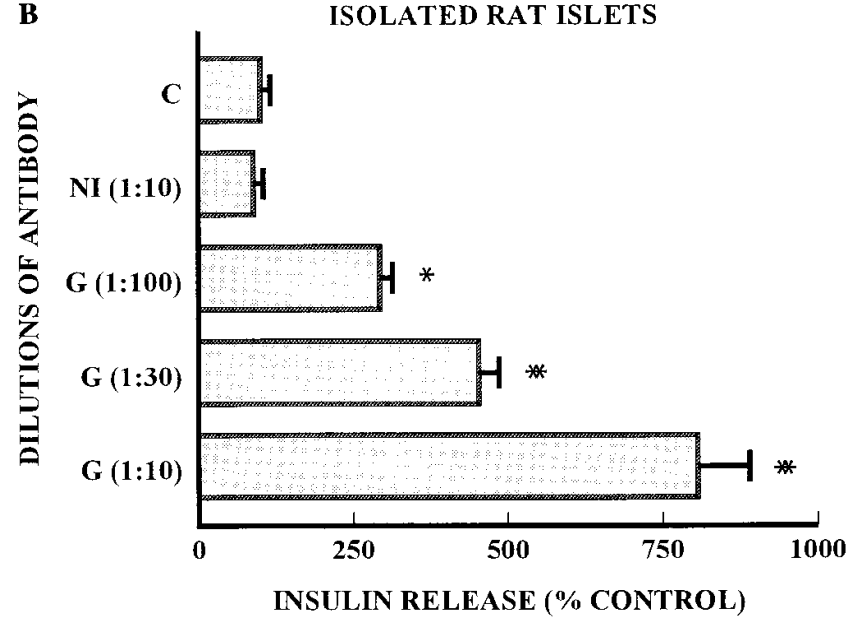

Figure 4. Purified anti-GAb induced increases in insulin release from incubated $(A)$ RIN5AH cells $(n=6)$ and $(B)$ rat islets $(n=6)$ at three dilutions: $\mathrm{G}(1: 100),(1: 30)$, and $(1: 10)$, vol/vol. $* P<0.01, * * P<0.001 \mathrm{vs.} \mathrm{non-immune}(N I)$ serum treated control. The control insulin secretion for RIN5AH cells was $0.31 \pm 0.03 \mathrm{pmol} / 10^{6}$ cells per $\mathrm{h}$. The control insulin secretion for the islets was $2.6 \pm 0.4 \mathrm{fmol} / \mathrm{islet}$ per min.

served between treated and control chambers in the subsequent periods of perifusion (data not shown).

\section{Effect of immune-purified galanin antibody on insulin release}

RIN cells. Incubation of RIN5AH cells with immune purified $\mathrm{GAb}$ resulted in an increase in insulin release at the three dilutions used with an increase of $46 \%$ at the lowest dilution, $1: 10$, $\mathrm{vol} / \mathrm{vol}$, compared to nonimmune serum control (all dilutions $P<0.01$ vs. control, $n=6$, Fig. $4 A$ ). No differences were observed between no-antiserum controls and nonimmune serum controls $(P=\mathrm{NS}, n=4)$. The purified antisera against pneumadin and bombesin did not affect insulin secretion relative to that of no-antiserum control and nonimmune serum treated control cells (data not shown).

Isolated islets in static incubation. Insulin secretion was increased from isolated islets in response to incubation with decreasing dilutions of the purified antibody, as for RIN5AH cells. An approximately eightfold rise in insulin release was seen at the lowest antibody dilution used [control vs. GAb (1:100) $P<0.01$; control vs. GAb (1:30) $P<0.001$; control vs. GAb (1:10) $P<0.001$, all $n=6$, Fig. $4 B$ ]. Insulin release from islets treated with nonimmune serum was not different from that of control islets treated with no antiserum.

\section{Assay for galanin immunoreactivity}

Galanin immunoreactivity was not detected in the perifusate samples, extracts of islets, or in culture media and extracts of RIN5AH cells. However, extracts of rat ileum (positive control) showed the presence of galanin immunoreactivity $(142 \pm 18 \mathrm{pmol} / \mathrm{mg}$ wet wt, $n=3)$.

\section{Western blotting}

Blot A. Analysis of tissue and cell extracts for galanin-like immunoreactivity was carried out by Western blotting using the purified porcine GAb previously used in the cell and islet experiments. Fig. $5 \mathrm{~A}$ shows the presence of a strong immunoreactive band of $\sim 4 \mathrm{kD}$ in the positive control lane loaded with porcine galanin and a faint band in the lane loaded with rat galanin. A signal corresponding to a similar molecular mass was also observed in islet extracts from dexamethasonetreated rats but not normal rats.

Blot B. Western blotting using a rat specific GAb showed a strong band in the lane loaded with rat galanin (Fig. $5 \mathrm{~B}$ ). No other bands were detected.

\section{Discussion}

Galanin is generally known to inhibit glucose-induced insulin release. The inhibitory effect of galanin on insulin release is via a specific galanin receptor on the $\beta$ cell linked to a pertussis

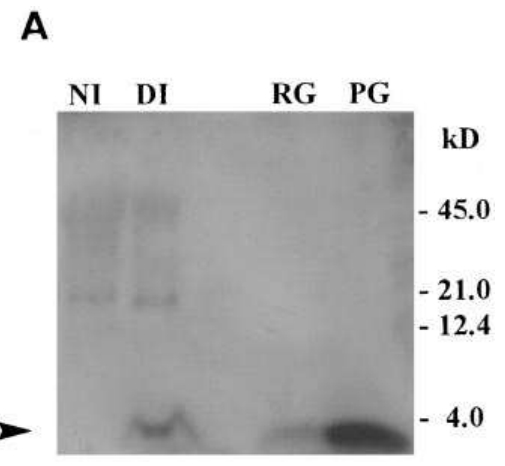

B

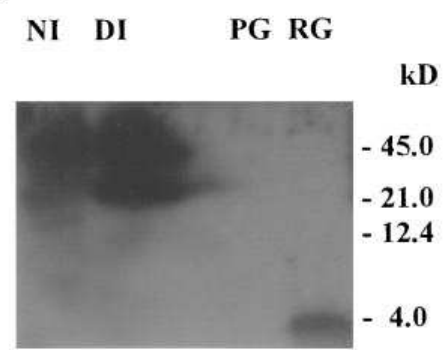

Figure 5. Representative Western blots for the galanin-like peptide using a purified primary antibody specific for $(A)$ porcine or $(B)$ rat galanin. $N I$, islets from normal rats; $D I$, islets from dexamethasone-treated rats; $R G$, rat galanin standard (loaded $20 \mu \mathrm{g}$ in blot $\mathrm{A}$ and $1 \mu \mathrm{g}$ in blot B); $P G$, porcine galanin standard (loaded $1 \mu \mathrm{g}$ in blot $\mathrm{A}$ and $20 \mu \mathrm{g}$ in blot B). Molecular masses in kilodaltons are shown on the right $(n=4)$. The arrowhead indicates the band in the sample lane corresponding to islets from dexamethasone-treated rats. 
toxin-sensitive $\mathrm{G}$ protein (33). Several chimeric peptide antagonists have been used to characterize putative galanin receptor subtypes. C7 has been shown to be a high-affinity antagonist at the galanin receptor (34) and the nonmethionine containing M35 has been reported to antagonize the inhibitory effects of galanin in isolated mouse islets (35). Both C7 and M35 have a high oxidative stability and bind to more than one type of receptor, i.e., substance P for C7 and bradykinin for M35. Although these chimeras are antagonists in physiological assays (36-38) their bireceptor recognition property may confound their actions in tissues where both these receptors are present. On the other hand, M40 is galanin (1-13) coupled to a sequence at the carboxyl terminus designed to adopt an $\alpha$-helical structure which stabilizes the interaction of the ligand with the galanin receptor at the membrane (39). M40 shows an antagonist activity in brain areas like the hypothalamus and the hippocampus but has been reported to be an agonist in the pancreas $(36,40,41)$.

We have demonstrated galanin binding sites on membranes prepared from RIN5AH cells. The $K_{\mathrm{d}}$ for galanin was lower than for all the antagonists, suggesting a greater affinity of galanin for its receptor. The $K_{\mathrm{i}}$ values for the antagonists were in the nanomolar range, indicating that the antagonists also had a high affinity for the receptor. These values are in the range for galanin previously described for membranes prepared from another rat insulinoma cell line, RINm5F (32). Furthermore, $\mathrm{B}_{\max }$ was similar to that reported for galanin binding sites on RINm5F cell membranes $(42,43)$. Galanin suppressed insulin secretion in the RIN5AH cells in a dosedependent manner. An attenuation of the inhibition of $100 \mathrm{nM}$ galanin on glucose-stimulated insulin release was evident with $100 \mathrm{nM} \mathrm{C7}$ and $1 \mu \mathrm{M}$ M35 or M40. Another study carried out on RINm5F cells has shown that M35 acts as a galanin antagonist at low concentrations $(<10 \mathrm{nM})$ and as an agonist at doses $>10 \mathrm{nM}$ (41). This report (41) is at variance from our results and warrants further investigation.

C7 alone gave a further $50 \%$ increase in glucose-stimulated insulin secretion in the perifused islets and a twofold increase in the RIN5AH cells. As C7 is a chimeric peptide composed of galanin(1-12)-proline linked to spantide, a substance $\mathrm{P}$ antagonist (34), it is conceivable that the actions of C7 may be mediated by the substance $\mathrm{P}$ antagonist component. We tested this possibility by incubating RIN5AH cells with substance $\mathrm{P}$ and spantide. The lack of any influence of these compounds on insulin secretion, as reported previously for RINm5F cells (44), suggests that the effects of $\mathrm{C} 7$ are unlikely to be by interaction with substance $\mathrm{P}$ receptors. Similar insulin stimulatory responses were observed when M35 was tested in the RIN5AH cells. The M35 sequence consists of bradykinin(2-9) at its carboxyl-terminal end. To our knowledge, no bradykinin receptors have been reported on pancreatic $\beta$ cells nor have they been found on membranes prepared from the clonal cells RINm5F (35). Furthermore, bradykinin failed to induce any change on insulin secretion in RIN5AH cells. Therefore, M35 is unlikely to act via bradykinin receptors. In a study on mouse islets M35 did not have any effect on glucose-stimulated insulin release up to concentrations of $1 \mu \mathrm{M}$ (35). The stimulatory glucose concentration used in that study was $11 \mathrm{mM}$. It is possible that this concentration is high and may have masked any further stimulatory effects of M35. We used a submaximal stimulatory glucose concentration in RIN5AH cells to avoid this problem. M40 also stimulated insulin release, albeit at a higher dose of $10 \mu \mathrm{M}$. M40 is another antagonist with a structural configuration believed to stabilize its interaction with the galanin receptor and without a bireceptor recognition property (39). The stimulatory action of M40 both in the islets and the RIN5AH cells therefore confirms the effects of C7 and M35 and suggests that they are undoing a galanin-like action of a substance inhibitory to insulin release.

We also tested the effect of immune-purified porcine $\mathrm{GAb}$ on glucose-stimulated insulin release in RIN5AH cells and isolated islets. A significant dose-dependent increase in insulin secretion was observed at the three dilutions of antibody in RIN5AH cells. A much stronger but qualitatively similar effect was observed in the isolated rat islets. The antibody was much more concentrated in the immune blockade experiments (1:100) than the limiting dilution necessary for the RIA used to detect galanin-like immunoreactivity in the islet and RIN5AH cell extracts $(1: 256,000)$. Polyclonal antibodies are known to contain different epitopes in varying quantities (45). It is possible that the concentration of the specific antibody to the epitope required to inhibit the presumed galanin-like peptide was present in adequate concentrations to suppress the inhibitory effect at the concentration used in immune blockade but not in sufficient quantities for detection under the conditions of the RIA. Treatment with antisera raised against pneumadin and bombesin did not affect insulin release, suggesting that the effect of the galanin antibody is specific.

Using a purified porcine GAb we were able to detect a signal of similar molecular mass to galanin using Western blotting in islets isolated from dexamethasone-treated rats. The lack of a signal in these samples immunoblotted using the purified rat antibody suggests that the detected signal is unlikely to be endogenous galanin. The faint band in the lane loaded with rat galanin in blot A confirms the $\sim 20 \%$ cross-reactivity in the galanin RIA. Dexamethasone treatment has been shown to induce the expression and increase the content of other islet peptides like neuropeptide tyrosine $(13,46)$, vasoactive intestinal peptide, and calcitonin gene-related peptide (13). Although we were unable to detect a signal in normal islets and RIN5AH cells, it is possible that levels are low in these tissues and that the galanin-like peptide may be induced to detectable levels by dexamethasone treatment.

We have been unable to detect galanin in acid-ethanol extracts of islets from normal rats or RIN5AH cells by means of RIA of high sensitivity. For the RIA, $\sim 10,000$ islets and $5 \times$ $10^{7}$ RIN5AH cells were isolated and extracted separately. The detection limit of the assay is $2 \mathrm{fmol} /$ tube, therefore the maximum amount of galanin that could be present in the islets, for example, would be $2 \mathrm{fmol} / 10,000$ islets or $0.2 \mathrm{amol}$ per islet. If one assumes the total volume during a static incubation of 100 islets was $1 \mathrm{ml}$, the calculated concentration would have a value of $\sim 20 \mathrm{fM}$. Studying the displacement curve from the receptor-ligand experiments (Fig. 1), this concentration of galanin would not be expected to give any effect. It must be emphasized here that we have used a perifusion model and the volume is actually much greater than $1 \mathrm{ml}$. In reality the calculated value would therefore be much lower than $20 \mathrm{fM}$. We believe that the results reported in this study are better explained by a structurally related galanin-like peptide rather than a small amount of true galanin. Further, the perifusion model involves continuous washing out of secreted products from the islets. In such a system it is likely that any residual galanin would be quickly removed. Galanin-like encoding mRNA was 
not detectable in islet RNA by Northern blot analysis $(13,14)$. It seems unlikely that appreciable authentic galanin is produced in normal islets. One possibility is that a galanin-like peptide is present and that the antagonists are blocking the inhibitory effect of this endogenous peptide.

These results, obtained independently in two different cell systems, using either galanin antagonists or a purified galanin antibody, suggest that the increase in insulin release observed may be due to blocking the effect of an endogenously produced galanin-like peptide, thus preventing an autocrine inhibitory effect. The Western blotting data provide additional evidence for the presence of this putative galanin-like peptide. However, further studies are needed to purify and characterize the peptide before we can define its physiological role.

\section{Acknowledgments}

We wish to thank Dr. J.K. Howard for help with the Western blotting.

This work was supported by grants from the Medical Research Council, United Kingdom, and The Special Trustees of Hammersmith Hospital, United Kingdom. R.N. Kulkarni is the recipient of the Overseas Research Students Award and the Weston Scholarship.

\section{References}

1. Tatemoto, K., ̊. Rökaeus, H. Jornvall, T.J. McDonald, and V. Mutt. 1983. Galanin - a novel biologically active peptide from porcine intestine. FEBS (Fed. Eur. Biochem. Soc.) Lett. 164:124-128.

2. Rökaeus, Å. 1987. Galanin: a newly isolated biologically active neuropeptide. Trends Neurosci. 10:158-164.

3. Lindskog, S., B. Ahren, B.E. Dunning, and F. Sundler. 1991. Galanin immunoreactive nerves in the mouse and rat pancreas. Cell Tissue Res. 264:363368.

4. Shimosegawa, T., S. Moriizumi, M. Koizumi, J. Kashimura, N. Yanaihara, and T. Toyota. 1992. Immunohistochemical demonstration of galaninlike immunoreactive nerves in the human pancreas. Gastroenterology. 102:263-271.

5. McDonald, T.J., J. Dupre, K. Tatemoto, G.R. Greenberg, J. Radziuk, and V. Mutt. 1985. Galanin inhibits insulin secretion and induces hyperglycaemia in dogs. Diabetes. 34:192-196.

6. Hramiak, I.M., J. Dupre, and T.J. McDonald. 1988. Effects of galanin on insulin responses to hormonal, neuropeptidal and pharmacological stimuli in conscious dogs. Endocrinology. 122:2486-2491.

7. Scheurink, A.J.W., T.O. Mundinger, and R.C. Veith. 1990. $\alpha 2$-adrenergic modulation of galanin release from canine pancreas: evidence for co-release with norepinephrine. Diabetes. 39(Suppl.):A139.

8. Dunning, B.E., P.J. Havel, R.C. Veith, and G.J. Taborsky, Jr. 1990. Pancreatic and extrapancreatic galanin release during sympathetic neural activation. Am. J. Physiol. 258:E436-E444.

9. Ahren, B., and S. Lindskog. 1992. Galanin and the regulation of islet hormone secretion. Int. J. Pancreatol. 11:147-160.

10. Dunning, B.E., B. Ahren, R.C. Veith, F. Bottcher, F. Sundler, and G.J. Taborsky, Jr. 1986. Galanin: a novel pancreatic neuropeptide. Am. J. Physiol. 251:E127-E136.

11. Dunning, B.E., B. Ahren, F. Bottcher, F. Sundler, and G.J. Taborsky, Jr. 1987. The presence and actions of NPY in the canine endocrine pancreas. Regul. Pept. 18:253-265.

12. Dunning, B.E., and G.J. Taborsky, Jr. 1988. Galanin-sympathetic neurotransmitter in endocrine pancreas? Diabetes. 37:1157-1162.

13. Jamal, H., P.M. Jones, J. Byrne, K. Suda, M.A. Ghatei, S.M. Kanse, and S.R. Bloom. 1991. Peptide contents of neuropeptide Y, vasoactive intestinal polypeptide, and $\beta$-calcitonin gene-related peptide and their messenger ribonucleic acids after dexamethasone treatment in the isolated rat islets of Langerhans. Endocrinology. 129:3372-3380.

14. Kaplan, L.M., E.R. Spindel, K.J. Isselbacher, and W.W. Chin. 1988. Tissue-specific expression of the rat galanin gene. Proc. Natl. Acad. Sci. USA. 85: 1065-1069.

15. Timmers, K., D.L. Coleman, N.R. Voyles, A.M. Powell, A. Rökaeus, and L. Recant. 1990. Neuropeptide content in pancreas and pituitary of obese and diabetes mutant mice: strain and sex differences. Metabolism. 39:378-383.

16. Dunning, B.E., and B. Ahren. 1992. Reduced pancreatic content of the inhibitory neurotransmitter galanin in genetically obese, hyperinsulinemic mice. Pancreas. 7:233-239.
17. Dunning, B.E., S. Karlsson, and B. Ahren. 1991. Contribution of galanin to stress-induced impairment of insulin secretion in swimming mice. Acta. Physiol. Scand. 143:145-152.

18. Karlsson, S., and B. Ahren. 1990. Effects of autonomic receptor blockade on the insulin- and glucagon responses to a standardized swimming-stress in mice. Metabolism. 39:724-732.

19. Wang, Z., R.N. Kulkarni, W.M. Bennet, R. Wang, D.M. Smith, M.A. Ghatei, and S.R. Bloom. 1995. Evidence for the presence of a galanin-like hormone within pancreatic islets. Diabetes. 44(Suppl.):249A

20. Karlsen, A.E., W.Y. Fujimoto, P. Rabinovitch, S. Dube, and A. Lernmark. 1991. Effects of sodium butyrate on proliferation-dependent insulin gene expression and insulin release in glucose-sensitive RIN5AH cells. J. Biol. Chem. 266:7542-7548.

21. Olmos, G., R.N. Kulkarni, M. Haque, and J. McDermot. 1994. Imidazolines stimulate release of insulin from RINAH cells independently from imidazoline I1 and I2 receptors. Eur. J. Pharmacol. 262:41-48.

22. Kulkarni, R.N., Z. Wang, K.O. Akinsanya, W.M. Bennet, R.M. Wang, D.M. Smith, M.A. Ghatei, P.G.H. Byfield, and S.R. Bloom. 1995. Pyroglutamyl-phenylalanyl-proline amide attenuates thyrotropin-releasing hormone stimulated insulin secretion in perifused rat islets and insulin-secreting clonal beta cell lines. Endocrinology. 136:5155-5164.

23. Bhogal, R., D.M. Smith, and S.R. Bloom. 1992. Investigation and characterization of binding sites for islet amyloid polypeptide in rat membranes. Endocrinology. 130:906-913.

24. Gornall, A.G., C.J. Bardawill, and M.M. David. 1949. Determination of serum proteins by means of the biuret reaction. J. Biol. Chem. 177:751-766.

25. Wynick, D., D.M. Smith, M. Ghatei, K. Akinsanya, R. Bhogal, P. Purkiss, P. Byfield, N. Yanaihara, and S.R. Bloom. 1993. Characterization of a high-affinity galanin receptor in the rat anterior pituitary: absence of biological effect and reduced membrane binding of the antagonist M15 differentiate it from the brain/gut receptor. Proc. Natl. Acad. Sci. USA. 90:4231-4235.

26. Lacy, P.E., and M. Kostianovsky. 1967. Method for the isolation of intact islets of Langerhans from the rat pancreas. Diabetes. 16:35-39.

27. Wang, Z.L., W.M. Bennet, M.A. Ghatei, P.G. Byfield, D.M. Smith, and S.R. Bloom. 1993. Influence of islet amyloid polypeptide and the 8-37 fragment of islet amyloid polypeptide on insulin release from perifused rat islets. Diabetes. 42:330-335.

28. Batra, V.K., M. Mathur, S.A. Mir, R. Kapoor, and M.A. Kumar. 1990. Pneumadin: a new lung peptide which triggers antidiuresis. Regul. Pep. 30:77-87.

29. Fracker, P.J., and J.C. Speck. 1978. Protein cell and membrane iodinations with a sparingly soluble chloroamide, 1,3,4,6-tetrachloro- $3 \alpha, 6 \alpha$-diphenylglycouril. Biochem. Biophys. Res. Commun. 80:849-857.

30. Wang, Z.-L., W.M. Bennet, R.-M. Wang, M.A. Ghatei, and S.R. Bloom. 1994. Evidence of a paracrine role of neuropeptide-Y in the regulation of insulin release from pancreatic islets of normal and dexamethasone-treated rats. Endocrinology. 135:200-206.

31. Montuenga, L.M., A. Martinez, M.J. Miller, E.J. Unsworth, and F. Cuttitta. 1997. Expression of adrenomedullin and its receptor during embryogenesis suggests autocrine and paracrine modes of action. Endocrinology. 138:440-451.

32. Amiranoff, B., A.M. Lorinet, and M. Laburthe. 1989. Galanin receptor in the rat pancreatic cell line RINm5F. Molecular characterization by chemical cross-linking. J. Biol. Chem. 264:20714-20717.

33. Cormont, M., Y. Le Marchand-Brustel, E. Van Obberghen, A.M. Spiegel, and G.W. Sharp. 1991. Identification of G protein $\alpha$-subunits in RINm5F cells and their selective interaction with galanin receptor. Diabetes. 40:11701176 .

34. Bartfai, T., G. Fisone, and U. Langel. 1992. Galanin and galanin antagonists: molecular and biochemical perspectives. Trends Pharmacol. Sci. 13:312-317.

35. Gregerson, S., S. Lindskog, T. Land, U. Langel, T. Bartfai, and B. Ahren. 1993. Blockade of galanin-induced inhibition of insulin secretion from isolated mouse islets by the non-methionine containing antagonist M35. Eur. J. Pharmacol. 232:35-39.

36. Crawley, J.N., J.K. Robinson, U. Langel, and T. Bartfai. 1993 Galanin receptor antagonists M40 and C7 block galanin-induced feeding. Brain Res. 600:268-272.

37. Verge, V.M., X.J. Xu, U. Langel, T. Hokfelt, Z. Wisenfeld-Hallin, and T. Bartfai. 1993. Evidence for endogenous inhibition of autotomy by galanin in the rat after sciatic nerve section: demonstrated by chronic intrathecal infusion of a high affinity galanin receptor antagonist. Neurosci. Lett. 149:193-197.

38. Ogren, S.O., A. Pramanik, T. Land, and U. Langel. 1993. Differential effects of the putative receptor antagonists M15 and M35 on striatal acetylcholine release. Eur. J. Pharmacol. 242:59-64.

39. Bedecs, K., M. Berthold, and T. Bartfai. 1995. Galanin-10 years with a neuroendocrine peptide. Int. J. Biochem. Cell Biol. 27:337-349.

40. Leibovitz, S.F., and T. Kim. 1992. Impact of a galanin antagonist on exogenous galanin and natural patterns of rat galanin. Brain Res. 599:148-152.

41. Bartfai, T., U. Langel, K. Bedecs, S. Andell, T. Land, S. Gregerson, B. Ahren, P. Girotti, S. Consolo, R. Corwin, et al. 1993. Galanin receptor ligand M40 peptide distinguishes between putative galanin-receptor subtypes. Proc. Natl. Acad. Sci. USA. 90:11287-11291.

42. Lagny-Pourmir, I., B. Amiranoff, A.M. Lorinet, K. Tatemoto, and M. Laburthe. 1989. Characterization of galanin receptors in the insulin secreting 
cell line Rin m 5F: evidence for coupling with a pertussis toxin-sensitive guanosine triphosphate regulatory protein. Endocrinology. 124:2635-2641.

43. Kask, K., M. Berthold, J. Bourne, S. Andell, U. Langel, and T. Bartfai. 1995. Binding and agonist/antagonist actions of M35, galanin(1-13)-bradykinin(2-9)amide chimeric peptide, in Rin $\mathrm{m}$ 5F insulinoma cells. Regul. Pept. 59: 341-348

44. Lindskog, S., B. Ahren, T. Land, U. Langel, and T. Bartfai. 1992. The novel high-affinity antagonist, galantide, blocks the galanin-mediated inhibition of glucose-induced insulin secretion. Eur. J. Pharmacol. 210:183-188.

45. Berzofsky, J.A., and I.J. Berkower. 1984. Antigen-antibody interaction. In Fundamental Immunology. W.E. Paul, editor. Raven Press, New York. 595-644.

46. Myrsen, U., B. Ahren, and F. Sundler. 1996. Dexamethasone-induced neuropeptide $\mathrm{Y}$ expression in rat islet endocrine cells. Rapid reversibility and partial prevention by insulin. Diabetes. 45:1306-1316. 